\title{
Eser Değerlendirmesi: Dimitra PAPAGIANNI, Michael A. MORSE, Neandertal: Modern Bilim Onların Hikâyesini Yeniden Yazdı (The Neanderthals Rediscovered How Modern Science Is Rewriting Their Story), Çev. İlknur Urkan Kelso, Trend Yayınevi, Ankara 2017, 222 s. (ISBN: 978-9944-342-67-4)
}

İncelemelerime göre söz konusu kaynak; bilimsel verilerin ışığında kaleme alınmış yarı popüler bir kitap olup, Dimitra Papagianni ve Michael A. Morse tarafından ortak çalışma ile oluşturulmuş ve İlknur Urkan Kelso tarafından Türkçeye çevrilmiştir. Kitabın orijinal baskısı Birleşik Krallıkta faaliyet gösteren Thames \& Hudson Yayın Evinde 16,95\$ olup Türkiye'de ise yaklaşık olarak 30 TL ile neredeyse yarı fiyatına Türk okuyuculara kazandırılmıştır. Dolayısıyla güncel antropolojik araştırmalar konusunda bu önemli eseri Türkçeye kazandıran Trend Yayınevine ve çevirmen İlknur Urkan Kelso teşekkür ederiz.

Öncelikle belirtmeliyim ki kitabın son derece iddialı olan "Neandertal: Modern Bilim Onların Hikâyesini Yeniden Yazdı" adı ve yine kitap arka yazısında yer alan "Neandertallerin hikâyesi, yeni keşifler ve değer yargılarını altüst eden bilimsel yenilikler sayesinde değişikliğe uğramıştır" gibi ifadeler genel anlamda kitabın içeriğini karşılamaktadır.

Kitapta özellikle insan kökeni, insanın evrimi, modern insan (Homo sapiens) evrimsel kökeni hakkında çok geniş kapsamlı bilgiler verilmektedir. Arkeolojik kazılar sonucunda çıkan buluntulardan, müzelere, ilk insanların ya da Hominidlerin medya ve popüler kültür içerisindeki eksik ve yanlış anlatımlarına kadar birçok konuya değinilmektedir. Söz konusu kitap günümüzde popüler kültür içerisinde değerlendirilebilecek kurgu roman niteliğinde olmayıp daha çok not alıp araştırma yapmayı gerektirmektedir.

Kitabın konusu; ilk insansıların Afrika'daki yaşamlarından başlayıp süreç içerisinde Avrupa'ya yayılmasına ve burada evrilen tek tür olan Neandertal'e kadar ayrıntılı bir anlatım mevcuttur. Yine taş aletlerin yapımı ve günlük aktiviteler ele alınmaktadır. Bu doğrultuda kitap, Neandertal ve Sapiens'i her alanda karşılaştırmakta ve biz en yakın akrabalarımız olan Neandertal'lerin yeryüzünden nasıl silindiğini anlatmaktadır. Özet olarak, kendinden fiziksel anlamda üstün bir ırk olan Neandertal'leri zekâsıyla alt eden Sapiens'in, süreç içerisindeki varoluşu ve mücadelesi ifade edilmektedir.

\footnotetext{
* Doç. Dr., Van Yüzüncü Yıl Üniversitesi, Edebiyat Fakültesi, Arkeoloji Bölümü, hakanyilmaz@yyu.edu.tr
} 
İlk Neandertal kalıntıları Almanya'da Neander Vadisinde bulunmakta olup türe bulundukları vadinin adı verilmiştir. Sapiens ve Neandertal Homo heidelbergensis olarak aynı ortak atadan gelmektedir. Bu insan türü büyük ihtimalle Homo erectus'dan evrilmiştir ve bu ırkın bir kısmı Avrupa'ya göç etmiş bir kısmı Afrika'da kalmıştır. Afrika'daki kısım sapiense evrilirken Avrupa'da Neandertal evrilmekteydi.

Kitaba konu olan "Homo Neandertalensis"; günümüze kadar en çok buluntu veren ve Paleoantropoloji'de hakkında en çok yorum ve değerlendirme yapılan insan türü olduğu bilinmektedir. Söz konusu kitapta yazarların amacının, Neandertal'ler hakkında günümüze kadar ulaşan arkeolojik keşifler ve yeni bilimsel verilerin, değişen fikirlerin ve mevcut teorilerin 1şığında söz konusu türün yeniden yorumlanması, değerlendirilmesi ve hikâyesinin anlatılmasıdır. Bu doğrultuda kitapta ilk dikkatimizi çeken, “önsöz ”de yazarların kitabın amacını açık şekilde ifade etmeleridir. Kitap akademik olmasına karşın Neandertal hikâyesini okuyucuya heyecan verici ve dramatik bir anlatımla sunmaktadır ve aynı zamanda uzun zamandır bu türe olan ön yargılı ve asılsız değerlendirmeleri dikkat çekici bir anlatımla yıkmaktadır.

Yazarların son yıllarda Avrupa'da Neandertal öncesi en erken insan buluntuları hakkındaki son teori ve hipotezleri, doğru bir sunumla ifade ettikleri dikkat çekmektedir. Ayrıca iklimsel dalgalanmalar hakkındaki teorileri ve gerçekleştirilen çalışmaların kronolojik bir anlatımla bir arada verilmesi etkileyicidir.

Kitapta, Avrupa'daki Homo Neandertal'lerin, arkaik Afrika'daki Homo sapiens'ler ile paralel olarak evrimleştikleri ve bu iki türü son ortak atalarının da Homo heidelbergensis olduğuna dair ilgili kısım, okuyucuya akıcı bir dil ile aktarılmıştır. Bu doğrultuda yazarlar Homo heidelbergensis'in Avrupa'da iki türle temsil edilebileceğini ve bu türlerin nüfusunun bir bölümünün Neandertal'lere evrilmiş olabileceği gibi henüz yanıtlanmamış birçok hipotezleri de okuyucuya vermektedir. Söz konusu kitapta, konu ile ilgili son arkeolojik keşifler, yeni tarihlendirmeler ve güncel bilimsel teknikler özellikle de Antik DNA teknolojisindeki gelişmeler 1şı̆̆ında, Homo sapiens ve Homo Neandertal'lerin Asya'da karşılaştıklarını, bir süre birlikte aynı yaşam alanını paylaştıkları gerçeğini yeniden değerlendirmemize ve dolayısıyla konu ile ilgili yeni keşifleri öğrenmemize olanak sağlamaktadır. Ayrıca yazarlar, Neandertal davranışlarının sanılanın aksine şaşırtıcı derecede modern davranış gösterdiklerini içeren birçok kanıtı da sunmaktadır. Kitapta modern davranış biçimine örnek olarak; ölülerini gömdükleri, hastalarına baktıkları, iri cüsseli hayvanları sürüler halinde uçurumdan atabildikleri, giysi ve ateşi geliştirebildikleri, ileriye dönük planlama yapabildikleri, sembolik amaçlarla kırmızı aşı boyası kullanabildikleri, konuşma dili ile iletişim kurabildikleri ve deniz ürünlerini tükettikleri belirtilmektedir. 
Kitap; Neandertal'lerin ortaya çıkışına kadar geçen süreyle ve Neandertal'lerin insan soy ağacındaki yerini anlamakla ilişkili en son teori ve hipotezleri, bilimsel ve kronolojik olarak doğru bir sunumla ifade etmektedir. Nitekim kitapta, Neandertaller hakkında son arkeolojik keşifler ve genetik veriler iyi sentezlenmiştir. Ayrıca Neandertal'lerin yaşamları üzerine dramatik bir portre çizilmiş olması, okuyucuya Neandertal'lere karşı duygusal bakış açısı kazandırmıştır.

Bu kitap her ne kadar Neandertal'ler hakkında yazılmış olsa da, yazarlar Homo sapiens' in paralel gelişimiyle ilişkili kanıtları da kitap içerisinde dengeli bir şekilde ifade etmiştir. Örneğin kitabın 120-121'inci sayfalarında belirtilen erken modern insanlarla ilgili gelişmeler, sayfa 124-127 arasında ifade edilen Homo sapiens'in Afrika'dan ayrılış serüveni, sayfa 164'de Avrupa'da Homo sapiens yerleşim yerleri ve sayfa 180-181'de Denisovanlilarla ilgili yeterli bulguların sunulması okuyucuya Neandetal dünyasından farklı bir döneme götürerek farklı insan türleri ile ilgili muhakeme yapabilme olanağı sağlamaktadır.

Ayrıca yazarlar birçok insanın aklını karıştıran bir hususu da dile getirmektedirler. Bu konu da süreç içinde neden sadece Homo sapiens'in hayatta kaldığı sorusudur. Her ne kadar kitapta bu sorunun cevabı tatmin edici bir şekilde cevaplandırılmamış olsa da yazarlar konuyu farklı bir bakış açısıyla anlatmaya çalışmışlardır. Bu bakış açısına göre; Homo sapiens'in hayatta kalması, Neandertal'lerin dünya sahnesinden çekilmeleriyle ilgili görüşlerin ayrıntılarında gizlenmiştir.

Ancak kitapta eleştirilecek önemli bir husus da yazarların Anadolu'daki Neandertal öncesi veriler hakkında bilgileri görmezden gelmeleridir. Örneğin Konya Dursunlu; Neandertal öncesi insan yaşamı hakkında yürütülen mevcut teori ve tartışmalara yardımcı olabilecek bulgular sunmaktadır. Dolayısıyla yazarların Anadolu'da keşfedilmiş Neandertal öncesi insan kalıntıları hakkındaki bu bilgileri sunmamaları kitap için eleştirilebilecek bir husustur.

Yine kitapta eleştireceğimiz bir nokta; sayfa 167'de modern insanın Avrupa'ya yayılımında kullanıldığı düşünülen rotalar hakkındaki sunulan kanıtlardır. Bunlar modern insanların; Türkiye, Bulgaristan ve Romanya üzerinden Avrupa'ya girdiği ve bu rotalar üzerindeki en eski modern insan yerleşimlerinden bahsedildiği bilgilerdir. Nitekim Avrupa'ya giden yol güzergâhlarından biri olarak gösterilmesine rağmen Türkiye'deki en eski modern insan yerleşimlerinden birisi olan Üçağızlı Mağarasından bahsedilmemiştir. Bu eksiklik, yazarların Konya Dursunlu, Yarımburgaz, Karain ve Üçağızlı Mağarasını hiç tanımadıklarını veya yok saydıklarını göstermektedir. Türkiye'deki bu yerleşimler ile yeni buluntuların (antropolojik ve arkeolojik kazılar) Neandertal öncesi ve sonrası hakkında önemli kanıtlar sunduğu bilinmektedir. Bu yerleşim yerlerinin kitap içinde bahsinin geçmemesi sorgulanması gereken hususlardan birisi olarak dikkat çekmektedir. Konu ile ilgili şahsi fikrimiz, 
Türkiye'deki çalışmaların önemsenmemesi ve ülkemizin “insanlık tarihi” açısından öneminin görmezden gelinmesidir. Biliyoruz ki ülkemizde son yılarda paleolitik dönemlere ait birçok antropolojik ve arkeolojik kazılar yeni bilimsel yöntemlerle yapılmakta ve kazılar sonucunda ortaya çıkartılan veriler uluslararası platformlarda da sunulmaktadır. Dolayısıyla yazarların bu çalışmaları görmemeleri imkânsız görünmektedir. Dileğimiz, kitabın yeni geliştirilmiş baskılarında bu eksikliklerin giderilmesidir.

Yine yazarların kitabın son bölümü olan yedinci bölümde bahsettiği; "Neandertal'i içeren sinema filmleri, diziler, TV reklâmları, müzik grupları, popüler romanlar, karikatürler ve çizgi filmler gibi popüler kültürde Neandertal'ler hakkında vasat, gerçekçi olmayan yeniden canlandırmaların bugüne kadar okuyucunun algısını yanlış yönlendirdiği vurgulanmış ancak bölüm gereğinden fazla uzun tutulmuştur. Söz konusu eksikliklere rağmen yazarların Homo Neandertal'lerin itibarını yeniden kazandırmak konusunda detaylı bir çalışma yaptıkları aşikârdır. Kitap, akıcı ve açıklamalı anlatımı sayesinde hızlı bir şekilde okunmaktadır. Ayrıca yazarlar, kitap kaynakçasında hem genel okuyucu hem de akademik uzmanlaşmış okuyucular için kitapları, makaleleri, kurmaca eserleri ve görsel kaynakları kapsamlı olarak sunmuşlardır.

Son olarak ise kitabın Türkçe baskısında, kitap kapağında Neandertal'lerin dramatik hikâyesine paralel bir görselin yer alması ve "Neandertal" kelimesinin parlak siyah ve kabartılı olarak sunulması dikkat çekicidir. Kitap içerisinde yer alan siyah beyaz fotoğraflar, harita ve çizimler de aydınlatıcı bilgiler vermektedir. Toplam 16 sayfada (sayfa 65-72 ve 145-152) yer alan fotoğraflar, renkli ve kaliteli parlak kâğıda basılmıştır. Yine 98-102, 132135 ve 175-176. sayfalarda yer alan anahtar sözcükler, temel kavramlar, terminolojik terimler ve tamamlayıcı metinlerdeki bilgiler; açık, sade ve akıcı bir dilde yazılmıştır. 